\title{
SYSTEMIC AND PULMONARY BLOOD PRESSURE DURING CAESAREAN SECTION IN PARTURIENTS WITH GESTATIONAL HYPERTENSION*
}

\author{
Robert Hodgkinson, farkhanda J. Husain and Robert H. Hayashi
}

\begin{abstract}
ÁBSTRACT
Twenty severely pre-eclamptic patients requiring caesarean section for delivery were allocated to two groups. One group received epidural anaesthesia consisting of either $20 \mathrm{ml}$ of bupivacaine 0.75 per cent at L3-4 or $12 \mathrm{ml}$ at L1-2. The other group received general anaesthesia consisting of thiopentone, 40 per cent nitrous oxide and halothane 0.5 per cent. Mean arterial pressure (MAP), pulmonary artery pressure (PAP), pulmonary wedge pressure (PWP), and central venous pressure (CVP) were recorded at five-minute intervals for at least 60 minutes before operation and at least every two minutes during anaesthesia. Patients receiving general anaesthesia had pressures recorded every minute during tracheal intubation and ex tubation. There was a mean increase of MAP of $45 \mathrm{~mm} \mathrm{Hg}$, of PAP $20 \mathrm{~mm} \mathrm{Hg}$, and PWP $20 \mathrm{~mm} \mathrm{Hg}$ during intubation and extubation. Apart from a slight mean fall in MAP the parturients receiving epidural anaesthesia showed little change in these cardiovascular parameters.

It is concluded that tracheal intubation of patients with gestational hypertension produces an increase in MAP, PAP, and PWP which can lead to a significant risk of cerebral haemorrhage and pulmonary oedema. The value and dangers of using short-acting hypotensive agents to prevent these episodes of hypertension has still to be assessed. With epidural anaesthesia there is a danger of hypotension which can be treated with intravenous fluid replacement and ephedrine.
\end{abstract}

There are disadvantages to both general and regional anaesthesia for caesarean section in the parturient with gestational hypertension. Laryngoscopy and tracheal intubation of hypertensive patients, whether treated or not, produces greater increases in arterial blood pressure than in normotensive patients. ${ }^{1,2}$ In pre-eclampsia this may be associated with increased sensitivity to angiotensin and norepinephrine. ${ }^{3}$ These excessive swings in arterial pressure are cause for concern since, in various studies on gestational hypertension ${ }^{4,5.6}$ cerebral haemorrhage or oedema have been responsible for 29 to 53 per cent of deaths and cardiac failure for 10 to 29.5 per cent. The autopsy findings on 33 eclamptic patients ${ }^{7}$ showed cerebral haemorrhage in 57.6 per cent, cerebral oedema in 18.2 per cent and cardiac hypertrophy in 78.8 per cent.

Robert Hodgkinson, M.A., M.D., Associate Professor, Departments of Anesthesiology, Obstetrics and Gynecology. Farkhanda J. Husain, M.D., Assistant Professor, Departments of Anesthesiology, Obstetrics and Gynecology. Robert H. Hayashi, M.D., Assistant Professor, Department of Obstetrics and Gynecology.

The University of Texas Health Science Center at San Antonio, 7703 Floyd Curl Drive, San Antonio, Texas 78284, U.S.A

* Read at the joint meeting of the Obstetrical Anesthetists Association and the Society of Obstetric Anesthesia and Perinatology, Birmingham, England, October 1979.

Canad. Anaesth. Soc. J., vol. 27, no. 4, July 1980
The reduced blood volume associated with gestational hypertension is considered by many to be a contraindication to regional anaesthesia. Williams' textbook of obstetrics ${ }^{8}$ states "(E)pidural anaesthesia seldom, if ever, should be used in the presence of ... pregnancyassociated hypertension ... If caesarean section is to be done, anaesthesia with thiopental, nitrous oxide and a muscle relaxant has many advantages ... . With subarachnoid block or epidural block hypotension detrimental to the fetus, as well as the mother may occur." This view has support from the successful results of Pritchard and Pritchard ${ }^{9}$ in the treatment of eclampsia. They state "(C)onduction anesthesia has been urged by some ... for reasons that are not clear. Compared to normal pregnant women the great majority of women with eclampsia have marked hypovolaemia and at the same time lose more blood at delivery." In a review of II studies that compared blood volume in pre-eclamptic and normal parturients, Chesley ${ }^{10}$ found a mean decrease in blood volume of nine per cent in the pre-eclamptic patients. However, it should be noted that the parturient has an increase in blood volume and cardiac output of 40 per cent compared to the non-pregnant woman. Assali and Vaughn" concluded that "the slight decrease in blood volume observed in pre-eclampsia has no hemodynamic relevance." The pre-eclamptic 
TABLE I

Descriptions of Ten Parturients Receiving General anaesthesia

\begin{tabular}{|c|c|c|c|c|c|c|c|c|}
\hline \multirow[b]{2}{*}{ Age } & \multirow[b]{2}{*}{ Parity } & \multicolumn{2}{|c|}{ Hydralazine* $(\mathrm{mg})$} & \multirow{2}{*}{$\begin{array}{c}\mathrm{BP} \dagger \\
\text { (mm Hg) } \\
\text { before CS }\end{array}$} & \multirow{2}{*}{$\begin{array}{l}\text { Albumin- } \\
\text { uria }\end{array}$} & \multirow{2}{*}{$\begin{array}{l}\text { Apgar } \\
1 \& 5 \\
\text { mins }\end{array}$} & \multirow{2}{*}{$\begin{array}{l}\text { Wt. of } \\
\text { baby } \\
\text { (G) }\end{array}$} & \multirow[b]{2}{*}{ Comments } \\
\hline & & I.V. & I.M. & & & & & \\
\hline \multirow[t]{2}{*}{15} & 0 & 10 & 5 & $190-205$ & & & & \\
\hline & & & & $\overline{100-110}$ & $3+$ & $7-9$ & 3969 & Acute onset of pre-eclampsia \\
\hline \multirow[t]{2}{*}{39} & 3033 & 10 & - & $160-190$ & & & & \\
\hline & & & & $\overline{180-110}$ & $3+$ & $3-7$ & 1956 & Convulsion, epigastric pain \\
\hline \multirow[t]{2}{*}{20} & 1001 & 10 & 15 & $160-170$ & & & & \\
\hline & & & & $\overline{85-110}$ & $1+$ & $8-9$ & 3515 & Headache, epigastric pain \\
\hline \multirow[t]{2}{*}{18} & 0 & 10 & 10 & $130-155$ & & & & \\
\hline & & & & $\overline{95-110}$ & $3+$ & $8-9$ & 3388 & Headache \\
\hline \multirow[t]{2}{*}{26} & 0 & 5 & 10 & $160-170$ & & & & \\
\hline & & & & $\overline{80-90}$ & $3+$ & $4-7$ & 539 & - \\
\hline \multirow[t]{2}{*}{21} & 0 & 5 & 5 & $160-210$ & & & & \\
\hline & & & & $\overline{90-110}$ & $2+$ & $5-8$ & 3742 & $\begin{array}{l}\text { Convulsion, headache, } \\
\text { Class B diabetic }\end{array}$ \\
\hline \multirow[t]{2}{*}{22} & 2002 & 5 & 5 & $165-210$ & & & & \\
\hline & & & & $\overline{100-110}$ & $3+$ & $6-9$ & 3827 & Severe headache \\
\hline \multirow[t]{2}{*}{20} & 2002 & 5 & 5 & $140-160$ & & & & \\
\hline & & & & $\overline{90-110}$ & $3+$ & $5-9$ & 3189 & Epigastric pain, blurred vision \\
\hline \multirow[t]{2}{*}{20} & 0 & 10 & 5 & $120-170$ & & & & \\
\hline & & & & $\overline{80-100}$ & $2+$ & $2-7$ & 405 & Blurred vision \\
\hline \multirow[t]{2}{*}{28} & 0 & 5 & 10 & $150-180$ & & & & \\
\hline & & & & $\overline{80-100}$ & $3+$ & $9-10$ & 2563 & Headache \\
\hline
\end{tabular}

"Dose in three hours before caesarean section.

$\dagger B P$ in three hours before caesarean section.

patient is hypertensive "because she has a severe arteriolar vasoconstriction and her vascular capacity is constricted around a blood volume that fits it .... Even assuming 100 per cent reversal (an unlikely event) the contracted blood volume in pre-eclampsia would not be sufficient to alter the cardiac output unless the drug used to release the arteriolar constriction itself reduces the cardiac output."

Several authors have reported on the use of epidural anaesthesia to control blood pressure in the pre-eclamptic. In a study of 150 parturients with a blood pressure of at least $160 / 100 \mathrm{~mm} \mathrm{Hg}$ $(21.23 / 13.3 \mathrm{kPa})$ and proteinuria, Moir, et al. ${ }^{12}$ obtained an average blood pressure reduction of 20 per cent. In only five patients did the systolic pressure fall below $100 \mathrm{~mm} \mathrm{Hg}(13.3 \mathrm{kPa})$. James and Davies ${ }^{13}$ studied maternal haemodynamics and renal function in 20 patients with gestational hypertension. The blood pressure was at least $140 / 90 \mathrm{~mm} \mathrm{Hg}(18.62 / 11.97 \mathrm{kPa})$ on two occasions more than six hours apart. The mean fall in blood pressure varied from 5 to 10 per cent during the $6 \frac{1}{2}$ hours following the institution of the epidural block. One patient had a drop of mean arterial pressure of 33 per cent and required intravenous ephedrine in $7.5 \mathrm{mg}$ increments. The patient "did not prove hyper-reactive to this agent." The authors did not find any improvement in renal function.

The present study was designed to examine the advantages and disadvantages of regional and general anaesthesia on cardiovascular parameters in a small group of parturients with gestational hypertension subjected to caesarean section.

\section{Materials and Methods}

All patients suffered from severe gestational hypertension (pre-eclampsia or hypertension with superimposed pre-eclampsia) and required emergency caesarean sestion for delivery. Severe gestational hypertension was defined as a blood pressure (BP) of $21.28 / 13.3 \mathrm{kPa}(160 / 110$ $\mathrm{mm} \mathrm{Hg}$ ) or above on two occasions, two or 
TABLE II

Description of Ten Parturients Receiving Epidural Anaesthesia

\begin{tabular}{|c|c|c|c|c|c|c|c|c|}
\hline \multirow[b]{2}{*}{ Agc } & \multirow[b]{2}{*}{ Parity } & \multicolumn{2}{|c|}{ Hydralazine* (mg) } & \multirow{2}{*}{$\begin{array}{c}\mathrm{BP \dagger} \\
\text { (mm Hg) } \\
\text { before CS }\end{array}$} & \multirow{2}{*}{$\begin{array}{l}\text { Albumin- } \\
\text { uria }\end{array}$} & \multirow{2}{*}{$\begin{array}{l}\text { Apgar } \\
1 \& 5 \\
\text { mins }\end{array}$} & \multirow{2}{*}{$\begin{array}{l}\text { Wt. of } \\
\text { baby } \\
\text { (G) }\end{array}$} & \multirow[b]{2}{*}{ Comments } \\
\hline & & I.V. & I.M. & & & & & \\
\hline \multirow[t]{2}{*}{33} & 0 & 15 & 0 & $200-220$ & & & & \\
\hline & & & & $\overline{120-}$ & $4+$ & $7-8$ & 1191 & - \\
\hline \multirow[t]{2}{*}{25} & 1101 & 5 & 5 & $155-200$ & & & & \\
\hline & & & & $\overline{80-110}$ & $3+$ & $9-9$ & 3770 & Headache \\
\hline \multirow[t]{2}{*}{18} & 0 & 5 & 10 & $160-190$ & & & & \\
\hline & & & & $\overline{80-110}$ & $2+$ & 9-9 & 3096 & Headache, blurred vision \\
\hline \multirow[t]{2}{*}{20} & 0 & 5 & 5 & $120-185$ & & & & \\
\hline & & & & $75-110$ & $3+$ & $2-7$ & 1503 & Headache, blurred vision \\
\hline \multirow[t]{2}{*}{26} & 3030 & 10 & 0 & $160-170$ & & & & \\
\hline & & & & $\overline{90-110}$ & $2+$ & $8-9$ & 3005 & Headache \\
\hline \multirow[t]{2}{*}{15} & 0 & 10 & - & $155-165$ & & & & \\
\hline & & & & $\overline{100-110}$ & $3+$ & $8-9$ & 2424 & Convulsion \\
\hline \multirow[t]{2}{*}{28} & 0 & 5 & 10 & $160-170$ & & & & \\
\hline & & & & $\overline{90-120}$ & $2+$ & $9-9$ & 3487 & - \\
\hline \multirow[t]{2}{*}{18} & 0 & 10 & 10 & $160-210$ & & & & \\
\hline & & & & $\overline{110-125}$ & $3+$ & $7-9$ & 2370 & Headache, blurred vision \\
\hline \multirow[t]{2}{*}{23} & 1001 & 10 & 0 & $150-190$ & & & & \\
\hline & & & & $\overline{100-130}$ & $3+$ & $1-1$ & 653 & $\begin{array}{l}\text { Breech, headache, blurred } \\
\text { vision }\end{array}$ \\
\hline \multirow[t]{2}{*}{16} & 0 & 10 & 5 & $160-190$ & & & & \\
\hline & & & & $\overline{90-100}$ & $3+$ & $8-9$ & 2460 & Convulsion \\
\hline
\end{tabular}

*Dose in three hours before caesarean section.

$\uparrow \mathrm{BP}$ in three hours before caesarean section.

more hours apart, despite treatment with magnesium sulphate and hydralazine, a $3+$ albumin, or convulsions. The parturients are described in Tables I and II. All had received hydralazine 5 to $10 \mathrm{mg}$ intravenously, and 5 to $10 \mathrm{mg}$ intramuscularly in the three hours before operation. Magnesium sulphate 5 to $15 \mathrm{~g}$ had also been adminis. tered.

After the danger of complications had been reviewed, the patients' consent for operation, monitors, and general or epidural anaesthesia was obtained. An arterial line was inserted and a Swan-Ganz catheter passed at least one hour before operation. Mean, systolic, and diastolic blood pressures, pulmonary artery pressures (PAP), and pulmonary wedge pressures (PWP) were recorded at five-minute intervals for 60 to 240 minutes before operation and at least every two minutes during anaesthesia. The central venous pressure (CVP) in all patients was within normal limits before anaesthesia. Those patients receiving general anaesthesia had their $\mathrm{BP}, \mathrm{PAP}$, PWP, and CVP measured every minute for 10 minutes after induction, suction, and tracheal extubation. All pressures were measured on a Techtronix ${ }^{\mathbb{1}}$ Model 414, 3-Channel Monitor and recorded on a Techtronix Model 400, 4-Channel Recorder with continuous print-out.

Parturients were randomly allocated to two groups. One group received general anaesthesia consisting of thiopentone $\left(<3 \mathrm{mg} \cdot \mathrm{kg}^{-1}\right)$, succinylcholine $100 \mathrm{mg}$, nitrous oxide 40 per cent, halothane 0.5 per cent, and a succinylcholine 0.2 per cent infusion. Premedication consisted of an intravenous injection of glycopyrollate $0.2 \mathrm{mg}$. The other group received an epidural block consisting of either $12 \mathrm{ml}$ of bupivacaine 0.75 per cent at L1-2 or $20 \mathrm{ml}$ at L3-4.

\section{RESULTS}

The mean and standard error (SE) of the mean arterial blood pressure (MAP), PAP and PWP of the ten parturients receiving general anaesthesia is shown in Figure 1. The mean increase in MAP during intubation, suction, and extubation of the 


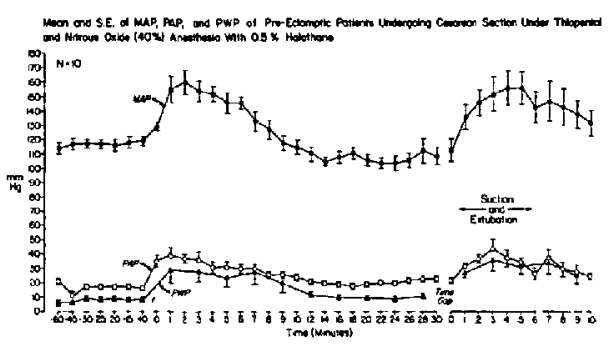

FIGURE 1 Values before induction of anaesthesia are indicated as -60 to -10 . The start of induction is indicated by the first " 0 ". The second " 0 " refers to the start of suction and extubation. The time gap refers to the time elapsing between the completion of the first 30 minutes of anaesthesia and the start of suction and extubation.

trachea was $5.99 \mathrm{kPa}(45 \mathrm{~mm} \mathrm{Hg})$; the mean increase in PAP was $2.66 \mathrm{kPa}(20 \mathrm{~mm} \mathrm{Hg})$, and PWP $2.66 \mathrm{kPa}(20 \mathrm{~mm} \mathrm{Hg})$. The largest increase in $\mathbf{B P}$ was from $26.6 / 11.97$ to $47.88 / 19.95 \mathrm{kPa}(200 / 90$ to $360 / 150 \mathrm{~mm} \mathrm{Hg}$ ) in one patient during suction and extubation.

The mean and SE of the MAP, PAP, and PWP of the ten parturients receiving epidural anaesthesia is shown in Figure 2. The mean MAP fell slightly, while the PAP and PWP remained essentially unchanged. The largest fall in $\mathrm{BP}$ in one individual patient was from $27.27 / 14.63$ to $12.64 / 5.32 \mathrm{kPa}(205 / 110$ to $95 / 40 \mathrm{~mm} \mathrm{Hg})$ occurring after 35 minutes of anaesthesia and immediately after the delivery of the baby. The CVP fell to zero. The BP returned to $17.29 / 5.32 \mathrm{kPa}$ $(130 / 40 \mathrm{~mm} \mathrm{Hg})$ within one minute following increase in the rate of fluid infusion and ephedrine $12.5 \mathrm{mg}$ intravenously.

\section{Discussion}

Both general and regional anaesthesia for caesarean section in the parturient with severe gestational hypertension can produce marked changes in cardiovascular dynamics. Under general anaesthesia the brief but severe episode of hypertension on tracheal intubation and extubation ${ }^{14.15}$ poses a threat of either cerebral haemorrhage or pulmonary oedema. Not only is the systemic pressure raised but there is also pulmonary hypertension with a rise in both the PAP and PWP. The rise in PWP seen in this study was not associated with pulmonary oedema. However, pulmonary oedema has been reported following tracheal intubation. ${ }^{16} \mathrm{We}$ have seen it on extubation of the trachea in three patients with severe pre-eclampsia. Cerebral haemorrhage has not been reported in relationship to general anaesthesia in pre-eclamptic parturients but it has

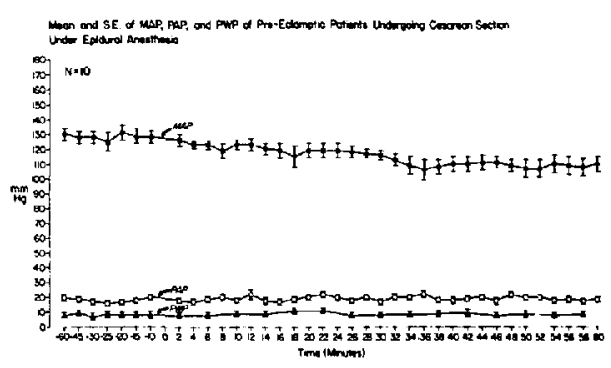

Figure 2 Values before the administration of the epidural injection of bupivacaine at " 0 " minutes are indicated as -60 to -10 and values during epidural anaesthesia as 2 to 60 .

been described in hypertensive patients. ${ }^{16} \mathrm{Con}$ vulsions in parturients with pre-eclampsia has been seen on extubation. ${ }^{17.18}$

The hypertension following tracheal intubation could probably be reduced by deeper anaesthesia, by the use of long-acting hypotensive agents such as hydralazine or by an infusion of short-acting hypotensive agents such as trimethaphan, nitroglycerine or nitroprusside. There is a consensus that deep anaesthesia is undesirable for caesarean section because of its effects on the foetus. Hydralazine was administered to all patients in this study but not at maximum dose. The effect of a large dose 20 to 30 minutes before tracheal intubation has to be evaluated. The short-acting hypotensive agents have four disadvantages. They increase intracranial pressure ${ }^{19}$ which could trigger a convulsion in a pre-eclamptic parturient. Secondly. sodium nitroprusside and presumably the other two agents have to be given prophylactically 15 seconds before laryngoscopy. ${ }^{20}$ Thirdly, there is a possible danger in producing hypotension in the foetus. Fourthly, none are approved by the Food and Drug Administration for this indication.

Regional anaesthesia, in contrast to general anaesthesia, may produce hypotension. The reduced blood volume of the pre-eclamptic patient compared to the normotensive parturient and the condemnation of regional anaesthesia in Williams' Obstetrics ${ }^{8}$ has led to a situation in which many hospitals never use epidural or spinal anaesthesia in the presence of gestational hypertension. However, Joyce, et al. ${ }^{21}$ state "... epidural analgesia/anesthesia can be safely and effectively used in the severe preeclamptic-eclamptic patient if appropriate volume replacement occurs prior to chemical sympathectomy." In their study of $\mathbf{4 0}$ mild to severe pre-eclamptic and eclamptic patients, 500 to $2000 \mathrm{ml}$ of lactated Ringer's solution and 250 to 
$750 \mathrm{ml}$ of plasmanate were needed to bring the central venous pressure (CVP) to $6-8 \mathrm{~cm} \mathrm{H}_{2} \mathrm{O}$. The importance of monitoring the CVP is also stressed by Marx and Wang. ${ }^{22}$ The incidence of hypotension in normal parturients undergoing caesarean section under epidural anaesthesia is low. Using $20 \mathrm{ml}$ of bupivacaine 0.75 per cent at L3-4, only 12 per cent of 147 parturients had a fall in systolic pressure below $100 \mathrm{~mm} \mathrm{Hg}$ and only three per cent required ephedrine. ${ }^{23}$ Whether the incidence of hypotension is higher in adequately hydrated pre-eclamptic patients remains to be assessed, although there are theoretical reasons ${ }^{\prime \prime}$ for believing it will not be higher than in normal parturients.

The fate of the neonates of parturients with gestational hypertension is related to progressive nutritional failure and prematurity. It is impossible to draw conclusions as to the relative risks of general and epidural anaesthesia on the basis of 20 cases. One baby in the epidural anaesthesia group weighed 653 grams and two babies in the general anaesthesia group weighed 539 and 405 grams. All three babies subsequently died. None of the deaths were attributed to anaesthesia. In each case, caesarean section was undertaken to arrest progressive worsening of the pre-eclamptic state in the presence of failed induction of labour.

\section{REFERENCES}

1. Dingle, H.R. Antihypertensive drugs and anaesthesia. Anaesthesia 2l: 151 (1966).

2. Prys-Roberts, C., Greene, L.T., Meloche, R. \& Fö̈x, P. Studies of anaesthesia in relation to hypertension. II: Haemodynamic consequences of induction and endotracheal intubation. Brit. J. Anaesth. 43: 53 (1971).

3. Talledo, O., Chesley, L. \& Zuspan, F. Reninangiotensin system in normal and toxemic pregnancies. Am. J. Obstet. Gynccol. 100: 218 (1968).

4. May, W.J., Greiss, F.C. \& ANDERSON, S.G. Maternal deaths from toxemia of pregnancy in North Carolina, 1946-1965. NC Med. J. 357 (1969).

5. Arthure, h., Tomkinson, J., Organe, G., LEWIS, E.M., ADELSTEIN, A.M. \& WEATHERALL, J.A.C. Report on Confidential Enquiries into $\mathrm{Ma}$ ternal Deaths in England and Wales 1970-72, London, H.M.S.O., Publ. (1975).

6. Hibiard, L.T. Maternal mortality due to acute toxemia. Obstet. Gynecol. 42: 263 (1979).

7. López-Llera, M., Linares, G.R. \& Horta, J.L.H. Maternal mortality rates in eclampsia. Am. J. Obstet. Gynecol. 124: 149 (1976).

8. Pritchard, J.A. \& McDonald, P.C. (Eds.) Wil- liams Obstetrics, New York, N.Y., AppeltonCentury-Crofts. 15th edition, p. 219 (1976).

9. Pritchard, J.A. \& Pritchard, S.A. Standardized treatment of 154 consecutive cases of eclampsia. Am. J. Obstet. Gynecol. 123: 543 (1975).

10. Chesley, L.C. Disorders of the kidney fluids and electrolytes. In: Pathophysiology of Gestation, N.S. Assali (Ed.), New York. N.Y., Academic Press, Inc. Vol. I: 437 (1972).

11. Assali, N.S. \& VAughn, D.L. Blood volume in pre-eclampsia: Fantasy and reality. Am. J. Obstet. Gynecol. 129: 355 (1977).

12. Moir, D.D., Victor-Rodriques, L. \& WILLocks. J. Epidural analgesia during labor in patients with pre-eclampsia. J. Obstet. Gynaecol. Brit. Commonw. 79: 465 (1972).

13. James, Francis M. III \& Davies, P. Maternal and fetal effects of lumbar epidural analgesia for labor and delivery in patients with gestational hypertension. Am. J. Obstet. Gynecol. 126: 195 (1976).

14. King, B.D., Harris, L.C., JR., Greifenstein, F.E., Elder, J.D., JR. \& Dripps, R.D. Reflex circulatory responses to direct laryngoscopy and tracheal intubation performed during general anesthesia. Anesthesiology 12:556 (1951).

15. Sorensen, M.B. \& Jacobsen, E. Pulmonary hemodynamics during induction of anesthesia. Anesthesiology 46: 246 (1977).

16. Fox, E.J., Sklar, G.S., Hill, C.H., VILLANUEVA, R. \& King, B.D. Complications related to the pressor response to endotracheal intubation. Anesthesiology 47: 524 (1977).

17. FORBES, A.M. \& DALLY, F.G. Acute hypertension during induction of anaesthesia and endotracheal intubation in normotensive man. Brit. J. Anaesth. 42: $618(1970)$.

18. Maternal and Perinatat Mortality Committee, New South Wales. Cesarean section in New South Wales 1966-1967. Med. J. Aust. I: 319 (1969).

19. Rogers, M.C., Hamburger, C., Owen, K. \& EPSTEIN, M.H. Intracranial pressure in the cat during nitroglycerine-induced hypotension. Anesthesiology 57:227 (1979).

20. Stoelting, R.K. Attenuation of blood pressure response to laryngoscopy and tracheal intubation with sodium nitroprusside. Anesth. Analg. (Cleve) 58: $116(1979)$.

21. Joyce, T.H. III, Debnath. K.S. \& Baker. E.A. Pre-eclampsia-relationship of CVP and epidural analgesia. Anesthesiology 5I: S297 (1979).

22. MARX, G.F. \& WANG, C.N. Anesthetic considerations in hypertensive disorders of pregnancy. In: Current Problems in Anesthesia and Critical Care Medicine, E.A. Brunner (Ed.), Chicago, London, Year Book Medical Publishers, Inc., 1: 8 (1978).

23. Hodgkinson, R. \& Husain, F.J. Obesity and the cephalad spread of analgesia following epidural administration of bupivacaine for cesarean section. Anesth. Analg. (In Press 1979).

RÉSUMÉ

Vingt patients en pré-éclampsie grave ont été divisées au hasard en deux groupes avant l'accouchement par césarienne. Celles du premier groupe ont été opérées sous péridurale ( $20 \mathrm{ml}$ de bupivacaïne à 0.75 pour cent injectés à $\mathrm{L}_{3} \mathrm{~L}_{4}$ ou $12 \mathrm{ml}$ du même agent à $\mathrm{L}_{1} \mathrm{~L}_{2}$ ). Une anesthésie générale (thiopental, protoxyde d'azote à 40 pour cent et halothane à 0.5 pour cent) 
a été administrée aux patients du second groupe. La pression artérielle moyenne, la pression de l'artère pulmonaire, la pression capillaire bloquée et la pression veineuse centrale, ont été enregistrées aux cinq minutes durant au moins une heure avant l'intervention et au moins aux deux minutes durant l'anesthésie. On a effectué les mesures aux minutes au cours de l'intubation et de l'extubation chez les patientes soumises à une anesthésie générale. Au cours de l'intubation et de l'extubation, on a observé des élévations moyennes de $5.99 \mathrm{kPa}(45 \mathrm{~mm} \mathrm{Hg})$ de la pression systémique moyenne et de $2.66 \mathrm{kPa}(20 \mathrm{~mm} \mathrm{Hg})$ dans les cas de la pression de l'artère pulmonaire et de la pression capillaire bloquée. On n'a observé qu'une légère diminution de la pression systémique moyenne chez les patientes opérées sous péridurale.

Donc, on retiendra que l'intubation trachéale chez les malades présentant une hypertension gravidique produit une élévation des pressions systémiques moyenne, pulmonaires et capillaires, avec un risque significatif d'hémorragic cérébrale et d'cedème aigu du poumon. Les avantages et les dangers liés à l'usage d'hypotenseurs d'action courte restent à évaleur chez ces malades. Un danger d'hypotension existe avec l'anesthésie péridurale, hypotension qui se traite avec une charge liquidienne et l'éphédrine. 